University of Michigan Law School University of Michigan Law School Scholarship Repository

2001

\title{
Detection of Deception: The Case of Handwriting Expertise
}

Samuel R. Gross

University of Michigan Law School, srgross@umich.edu

Available at: https://repository.law.umich.edu/articles/187

Follow this and additional works at: https://repository.law.umich.edu/articles

Part of the Evidence Commons

\section{Recommended Citation}

Gross, Samuel R. "Detection of Deception: The Case of Handwriting Expertise." Va. L. Rev. 87, no. 8 (2001): 1847-55.

This Article is brought to you for free and open access by the Faculty Scholarship at University of Michigan Law School Scholarship Repository. It has been accepted for inclusion in Articles by an authorized administrator of University of Michigan Law School Scholarship Repository. For more information, please contact mlaw.repository@umich.edu. 


\section{DETECTION OF DECEPTION: THE CASE OF HANDWRITING EXPERTISE}

\section{Samuel R. Gross*}

TN Shakespeare's Twelfth Night, Lady Olivia's renegade uncle, Sir Toby Belch, conspires with her maid, Maria, to set a trap for Malvolio, Olivia's officious, ambitious, and humorless steward. They plant an anonymous love letter that appears to be directed to Malvolio, in what seems to be Lady Olivia's handwriting. Malvolio finds it and falls for it:

\section{MALVOLIO:}

By my life, this is iny lady's liand. These be her

very c's, her u's and her t's and thus makes she her

great P's. It is in contempt of question lier hand. ${ }^{1}$

As usual, Shakespeare works at several levels. The deception of Malvolio is a comic parallel to the central plot-which turns on the noble Lady Viola's deception in pretending to be a man-and also an occasion for the stuck-up and puritanical Malvolio to blithely deliver two bawdy puns. ${ }^{2}$ For present purposes, I ain interested in the device that Shakespeare uses for this deception because it illustrates a central point in Professor Jennifer L. Mnookin's excellent article: Handwriting identification is old. As far back as the sixteenth century, it was widely believed both that handwriting was a distinctive mark tliat could identify the writer, and that such identifications could easily be mistaken, especially if the true writer was a clever forger. In Act V, after Malvolio has thoroughly liumiliated himself by bizarre behavior, he explains that he was acting on instructions in the letter and shows it to his mistress:

OLIVIA:

Alas Malvolio, this is not my writing, Though I confess much like the character, But out of question 'tis Maria's hand.'

- Thomas and Mabel Long Professor of Law, University of Michigan Law School.

${ }^{1}$ William Shakespeare, Twelfth Night, or What You Will, act 2, sc. 5.

${ }^{2}$ In case the audience misses them, Shakespeare has Sir Toby's sidekick, Sir Andrew Aguecheek, repeat the dirtier pun from his onstage hiding place: "Her c's, her u's, and her t's? Why that?" Id.

Id. at act 5, sc. 1. 
The basic method of handwriting identification is the same now as it was in Twelfth Night: to compare the questioned writing with other writings by the supposed writer. This can be done from memory if (like Malvolio) one is already familiar with the claimed author's handwriting, or by examining the questioned document together with known samples. It's a simple, obvious task. Any person-certainly any literate person-can have a go at it. The claim by handwriting experts, now and in the past, is equally simple: We can do it better.

On what basis did these experts presume that special skill? Mnookin argues persuasively that the form of handwriting expertise that became common in American courts developed in a context in which it was widely believed, across domains, that "careful observation" and measurement of "seemingly irrelevant detail"" would reveal underlying patterns that are hidden to the naked eye. As applied to human beings, this scientific culture produced the long discredited discipline of phrenology $y^{5}$ and the abandoned Berthillonage system of identification. ${ }^{6}$ It also produced the great lastimg success of early twentieth-century forensic science, fingerprint identification. There is nothing unique about the hit-and-miss quality of this overarching scientific methodology. For example, the great eigliteenth-century Swedish botamst Carolus Linnaeus is known today for developing the hierarchical taxonomy that we still use to classify the biological world. Linnaeus, however, was not aware either of the scientific basis for the success of his systemthat it happens to map neatly onto the process of differentiation by natural selection-or of its limitations. He apparently beheved that hierarchical organization is a basic principle of nature, and so, in addition to his justly famous system of classifying and naming animals and plants, he devised similar but useless and largely forgotten hierarchical schemes for classifying minerals and diseases. ${ }^{7}$ Our own misapprehensions will no doubt be equally clear two generations hence.

${ }^{4}$ Jennifer L. Mnookin, Scripting Exercise: The History of Handwriting Identification Evidence and the Judicial Construction of Reliability, 87 Va. L. Rev. 1723,1810 (2001).

sId. at 1809.

${ }^{6} \mathrm{Id}$.

${ }^{7}$ Stephen Jay Gould, Linnaeus's Luck?, 109 Nat. Hist. 18, 68-70 (Sept. 2000). 
Handwriting expertise has followed a peculiar intermediate course. It has not (so far) been so thoroughly discredited that it has been abandoned, like phrenology, but neither has it become securely established and accepted, like fingerprint identification. It is still widely used in courts and still widely disparaged. The disparagement is easy to understand; their own claims to the contrary notwithstanding, there is no substantial evidence that handwriting experts have any special skill at detecting forgeries. What is less clear is why courts allow handwriting experts to testify.

Polygraph experts, like handwriting experts, claim to be able to detect deception, but unlike handwriting experts, they have never been well received im court. ${ }^{8}$ Why did handwriting expertise fare so much better? Mnookin makes a persuasive case that expert evidence on handwriting became common because it filled an essential role. ${ }^{9}$ Faced with juries that had to struggle with decisions on the authenticity of disputed documents, even the most skeptical late nineteenth-century judges decided that handwriting expertise, however deficient, was no worse than the other sorts of evidence that were available. Karl Marx is supposed to have said (uncharitably) about John Stuart Mill: "It's not that Mr. Mill is so eminent, only that he seems so owing to the flatness of the surrounding terram. ${ }^{10}$ Handwritmg expertise may have benefited from this sort of comparison, which could help explain why it has survived as a form of expert evidence when other species of unreliable forensic science have flowered, withered, and become extinct."

Polygraph evidence, despite its flaws, is substantially more probative than handwriting analysis. ${ }^{12}$ This is not surprising; detecting

* The leading case is Frye v. United States, 293 F. 1013, 1014 (D.C. Cir. 1923) (rejecting polygraph evidence as a novel scientific technique that has not "gained general acceptance"). See 1 David L. Faigman et al., Modern Scientific Evidence: The Law and Science of Expert Testimony \$\$ 14-1.1 to 1.2, at 554-62 (1997).

${ }^{4}$ Mnookin, supra note 4, at 1761-62.

${ }^{10}$ I would be grateful to any reader who can supply a citation for the quotation. It can stand on its own, but deserves better.

"See, e.g., Andre A. Moenssens et al., Scientific Evidence in Civil and Criminal Cases $\$ 6.12$, at 341 (4th ed. 1995) (commenting on the rise and fall of the "diphenylamine paraffin test" for gunshot residue); Michael J. Saks, Merlin and Solomon: Lessons from the Law's Formative Encounters with Forensic Identification Science, 49 Hastings L.J. 1069, 1084-85 (1998) (noting the same for berthillonage).

${ }^{12}$ Compare, for example, Paul C. Giannelh, Polygraph Evidence: Post-Daubert, 49 Hastings L.J. 895, 903-24 (1998), and 1 Faigman, supra note 8, $\$ \$ 14-1.0$ to 7.0, at 554- 
a careful forgery on the basis of writings alone is surely even harder than spotting a lie. As common law trials are conducted, however, he-detector evidence is not necessary. Juries are presumed to be able to evaluate the credibility of the witnesses they see, unaided. In fact, the shoe is on the other foot. Polygraph and other lie-detector evidence is disfavored in part precisely because judging credibihty is viewed as a special and exclusive province of the jury. ${ }^{13}$

According to Mnookin, handwriting experts saw themselves (or at least presented theinselves) as scientists working within the accepted scientific framework of their time. ${ }^{14}$ My own fantasy is that turn-of-the-century handwriting experts imagined theinselves-or hoped to be seen-not so much as scientists but as scientific detectives. The archetype they aspired to was not Darwin, but that renowned, contemporary (if fictional) investigator of trace evidence, Sherlock Holmes. ${ }^{15}$ Holnes shows us the tell-tale signs-the fibers, the caked inud, the ashes, the dog that didn't bark-and then we know who did it, because that is how Sir Arthur Conan Doyle wrote the story. Usually, the culprit makes it simple by confessing or by taking soine desperate step, flight or attack, that confirms his guilt. Did this ever happen in court? Perhaps, on rare occasions. Handwriting experts doted over Perry Mason-like reports of their own heroic feats:

[Near the end of his testimony, the handwriting expert] paused, and then the forged signatures appeared upon the wall. There was a universal burst of admiration, and then all grew still-as if those who had given way to their feelings were suddenly stricken with the consciousness that they were witnessing a drama in which divine forces were playing a part. There were the ragged, jagged edges of the letters; there was the supplementary line, traceable in every party of them. There was man's he-revealed, defined, convicted by God's truth. [Shortly after,]

633 (polygraph examination), with 2 id. $\$ \$ 22-1.0$ to 2.0 , at $80-123$ (handwriting identification).

${ }^{13}$ See, e.g., State v. Beachman, 616 P.2d 337, 339 (Mont. 1980).

${ }^{14}$ Mnookin, supra note 4, at 1788-89.

${ }^{15}$ Edward Undercliffe, the fictional British handwriting expert in Charles Reade's play Foul Play, sounds like a close cousin to Sherlock Holmes. Mnookin, supra note 4, at 1799-1800 (citing 5 Charles Reade, Foul Play, in The Complete Writings of Charles Reade (London, Chatto \& Windus 1896)). 
and without leaving their seats the jury rendered a verdict for the whole amount of the damages claimed. ${ }^{16}$

As Mnookin recognizes, the recounting of these arresting tales, whatever their relationship to fact, was "a marketing effort" by handwriting experts. ${ }^{17}$ They are revealing, in part, as a clue to what these experts were trying to market themselves as.

Most cases, to say the least, did not end with opposing counsel agreeing that handwriting experts reign supreme. Like expert witnesses of all types, they were usually challenged and often ridiculed, and frequently opposing handwriting experts testified to irreconcilable conclusions. Mnookin focuses her attention on their successful efforts to convince courts that their field was sufficiently reliable for expert evidence to be admitted. But, in most cases, their inajor job must have been the expert witness's usual task: to convince the trier of fact to believe his testimony, and, if necessary, to reject that of opposing expert witnesses.

Mnookin argues that visual demonstration was a crucial element in handwriting experts' successful campaign to secure legal recognition. ${ }^{18}$ In the absence of any external market for their services, they needed to demonstrate in court that they possessed special knowledge, and they did so by showing it. The argument is plausible, but the case was overdetermined. For one thing, handwriting analysis is inherently visual; it is natural for judges and juries to want to see the evidence of telling similarities or irreconcilable differences between two writings. Fingerprint identification also deals with visible markings, albeit, unlike handwriting, unintentional ones. As a result, fingerprint evidence has also traditionally been presented in court with damning visual comparisons, ${ }^{19}$ despite overwhelming external evidence of its value, and despite the fact that it quickly attained star billing as a form of identification. ${ }^{20}$ Polygrapl examiners, by contrast, deal with oral deception. You cannot see a lie for yourself; you have to trust the expert and the

${ }^{16}$ J. G. Holland, Sevenoaks 406 (North River Bindery Co. 1901) (1875).

${ }^{17}$ Mnookin, supra note 4, at 1817.

${ }^{18}$ Id. at 1818-21.

${ }^{19}$ Id. at 1828; see also, e.g., Moenssens et al., supra note $11, \S \S 8.05,8.08$, at 503,515 (displaying reproductions of fingerprint exhibits used in courts); id. $\S 8.18$, at 543 (describing the use of such exhibits by prosecutors).

${ }^{20}$ See 2 Faigman, supra note $8, \S 21-1.0$, at $51-55$. 
machine. Even so, when polygraph experts do testify-not a common occurrence-I expect that they use visual aids as much as possible: machine tracings, graphs, photographs, whatever.

It may be true, as Mnookin claims, that handwriting analysts relied on visual comparisons in order to secure a berth in court as expert witnesses. But they would have done so anyway. Visual evidence is used by all experts, however unchallengeable the claims of their fields. Medical experts in malpractice and personal injury cases have never had to worry about the admissibility of their testimony, but they use visual demonstrations all the same. The best and highest paid among them work hard to make tlieir demonstrative exhibits clear and compelling. They do this to persuade the jury or the judge to believe their evidence, after it is admitted, so that their side may win.

Mnookin writes about the debate between the proponents of "education" as the proper function of expert testimony and the proponents of "deference" to the authority of the expert. ${ }^{21}$ I agree with her that wliat passes for education in the courtrooin always includes an essential, if generally unstated, appeal to authority. No expert, in any context, ever justifies all the steps that are necessary to her conclusions. Some premises-that she identified the right issues, for example, or chose the right method-are almost always accepted as given. These unexplained premises are not likely even to be mentioned. If we beheve the expert, we accept those premises under the global heading that "she knew what she was doing." If we doubt that, we are unlikely to trust her conclusions. For expert testimony on complex scientific or medical issues, the unexplamed portion inevitably dwarfs the explained; otherwise we would liave to retrain the waiters, stockbrokers, and civil servants on our juries as doctors manqué, would-be engineers, and quasiscientists.

Even so, in the mixed bag of education and deference, the use of visual demonstrations may seein like a move in the direction of education. I do not think it is. For better or for worse, the expert witness's job is not to educate but to persuade. That is what they are paid to do. Visual displays are an effective means of persuasion; that is why they are so widely used. Sometimes they amount

${ }^{21}$ Mnookin, supra note 4, at 1825-31. 
to cheap tricks and misdirection, with negative educational content. Even legitimate visual demonstrations are not a genuine attempt to educate the jury so that it may draw its own conclusions. They are offered in the service of an appeal to authority, as part of an overall attempt to persuade the jury to accept the expert witness's views rather than any competing argunents, includimg those from opposing experts. For this purpose, visual evidence is effective to the extent that is clear, interesting, and memorable-which may involve sacrifices in accuracy and completeness. Other forms of persuasion with no educational value-presenting impressive sounding credentials, for example, or generating confusion about the opponent's claims-are often used instead, or in tanden, im pursuit of the same goal. ${ }^{22}$

Handwriting expertise never achieved a high level of credibility as a discipline. Disagreements between handwriting experts were notorious-the most famous regularly derided some of the lesser lights as charlatans ${ }^{23}$-and they never established a clear record of success, in court or out. With so little going for them, it is not surprising to learn that they relied heavily on visual demonstrations as a means of persuasion. (Nonetheless, I have no doubt that the more celebrated ones-Daniel Ames and Albert S. Osborn-also made direct appeals to their own personal authority as worldfamous experts who had solved untold numbers of cases.) Fingerprint evidence, by contrast, quickly established an aura of infallibility. The major reason was the actual success of the technique. Once established, however, that reputation for infallibility became an independent basis for authority that fingerprint experts guarded by developing a professional norin against giving any testimony, however qualified, unless the examiner was "absolutely sure" of a positive identification. ${ }^{24}$

Mnookin poimts out that courts can sometimes confer a measure of scientific authority. ${ }^{25}$ In noost scientific contexts, I do not think judicial endorsements carry any significant weight. Some courts continued to admit expert testimony that traumatic injuries caused cancerous tumors long after that theory was discredited in nuedi-

\footnotetext{
${ }^{2}$ See Samuel R. Gross, Expert Evidence, 1991 Wis. L. Rev. 1113, 1158-76.

${ }^{23}$ Mnookin, supra note 4, at 1796-97.

${ }^{24} 2$ Faigman, supra note $8, \S 21-2.1 .2$, at 67 .

${ }^{25}$ Mnookin, supra note 4, at 1742 .
} 
cine, ${ }^{26}$ others still admit testimony on the future dangerousness of criminal defendants from psychiatrists who have never examined them, despite a strong consensus in the field that such predictions are worthless. ${ }^{27}$ Such cases bring dishonor to our courts, but have no effect on science or medicine. The so-called "forensic sciences," however, may be different. Because their sole function is to provide evidence for trials and pre-trial investigations, judicial acceptance may be more influential. For the general public, the scientific validity of fingerprint evidence and DNA identification is probably enhanced by the knowledge that they are universally rehed on in court. Handwriting experts probably benefitted from this process inore than any other profession, since they have no source of authority except in court, where their evidence is so widely accepted that it is sometimes considered a practical, if not a legal, requirement. The net effect, I suspect, is that this case study is in fact, as Mnookin suggests, sui generis. ${ }^{28}$

Here again, it is interesting to compare handwriting examination to polygraph examination, the other forensic science that aspires to detect deception. After the polygraph was rejected in court, polygraph examiners moved on and found other einployment. Thousands of them now make their hiving using the polygraph as a tool in criminal investigations and interrogations, and (more controversially) in screening investigations of einployees or applicants for employment in large organizations. Given the nature of their work, polygraph examiners have done hittle to make their disciphine acceptable to courts. On the contrary, common polygraph techniques would be embarrassing to describe to juries: the use of deception to enhance the anxiety of subjects in order to improve the effectiveness of the test, ${ }^{29}$ using the polygraph as a tool to trick suspects into confessions, ${ }^{30}$ and so forth. This commitment to outof-court investigation has become so coinplete that prominent polygraph examiners themselves argue that polygraph tests should not be admitted in evidence. ${ }^{31}$

${ }^{26}$ Gross, supra note 22 , at 1184 .

${ }^{27} \mathrm{Id}$. at 1184-85.

${ }^{28}$ Mnookin, supra note 4, at 1740.

${ }^{29}$ See 1 Faigman, supra note 8, § 14-3.1.1, at 586-87.

${ }^{30} 1$ id. $\$ 14-3.2 .6$, at 596 .

31 1 id. at 596-97. 
But what if Frye $e^{32}$ had gone the other way? What if, starting in 1923, polygraph evidence had been routinely admitted in American trials? Would public confidence in he detection by machine be higher than it now is, as Mnookin might predict? Perhaps. Judicial acceptance would certainly carry some weight, but on the otler side, the failures of the polygraph would also be more notorious. The inore important question is: How would the disciphine have developed if its evidence were readily admitted in court? What would polygraphy be in 2001, after seventy-eight years of steady use as expert evidence? Would adversarial scrutiny have improved practice in the field, or would admissibility in evidence have perpetuated techniques of doubtful value, as it seems to have done for handwriting analysis?

s2 293 F. 1013, 1014 (D.C. Cir. 1923). 